\title{
SOCIAL DIALOGUE IN THE FIELD OF LABOUR: DEFINITION AND LEGAL REGULATION
}

\section{Chanysheva G. I.}

\section{INTRODUCTION}

In Ukraine, the establishment of social partnership in the field of labour has been associated with the beginning of the 1990s. However, for a long period, the regulatory framework in this area remained unformed due to the lack of specific norms at the legislative level that would establish the legal foundations of the social dialogue. With the adoption of the Framework Law of Ukraine "On the Social Dialogue in Ukraine" of December 23, 2010, these gaps have been eliminated. For the first time in the national legislation the legal principles of organization and procedure of conducting social dialogue in Ukraine were defined with the purpose of elaboration and implementation of state social and economic policy, regulation of labour, social, economic relations and ensuring improvement of the level and quality of life of citizens and social stability in the society.

The development of the theory of social dialogue is one of the current trends in the research of the modern doctrine of labour law. Legal aspects of the social dialogue in the field of labour have been analyzed in the works of V.V. Zhernakov, V.I. Komarnitsky, P.D. Pilipenko, S.M. Prilipko, V.O. Protsevsky, M.V. Sorochishin, G.A. Trunova, O.M.Yaroshenko and others.

At the same time, despite the existence of the legislative definition of the concept, system and mechanism of social dialogue, there are different points of view regarding these categories in the doctrine of labour law.

In order to mark the process of defining and converging of positions, reaching common agreements and making of concerted decisions by the parties to the social dialogue that represent the interests of workers, employers, executive bodies and bodies of local self-government regarding the formation and implementation of state social and economic policies, regulation of labour, social, economic relations, the term "social dialogue" is used in national legislation.

At the same time, it should be noted that social dialogue is a complex multidimensional legal category and cannot be limited to a legislative definition. 
In addition to the legislative definition of the concept of social dialogue in article 1 of the Law of Ukraine "On the Social Dialogue in Ukraine" as a process of defining and converging of positions, reaching mutual agreements and making agreed decisions by the parties to the social dialogue, social dialogue should be considered as: 1) one of the basic principles of legal regulation of labour relations; 2) the system of collective labour relations; 3) as an institute of labour law.

The definition of the social dialogue in the field of labour should be analyzed, first of all as one of the basic principles of labour law, as a system of collective labour relations and as a legal institute in the system of this field.

\section{Social dialogue as one of the basic principles of labour law and the system of collective labour relations}

Principles of labour law are the most important fundamental foundations, the basis of this branch, which permeate the content of its norms and have a universal, general scope. One of the current tasks of the modern doctrine of labour law is a comprehensive study of the system of principles of the industry, based on the international and European labour standards, domestic legal tradition, comparative analysis of Ukrainian labour legislation and the legislation of foreign countries, and the practice of its application by law enforcement agencies. Separate principles of legal regulation of labour relations, including the principle of social dialogue in the field of labour, require special research.

In the context of the codification of the national labour legislation, researchers are tasked to formulate specific proposals regarding the legislative consolidation of the basic principles of legal regulation of labour relations in the draft Labour Code of Ukraine.

In the modern doctrine of labour law, the principles of legal regulation of labour relations are researched in the works of N.B. Bolotina, I.P. Zhigalkin, O.Ya. Lavriv, D.A. Pankov, O.V. Starchuk, G.I. Chanysheva and others. However, the principle of social dialogue in the field of labour has not yet been the subject of a special comprehensive study. Issues that require the attention of researchers should include the question of the definition and content of the above-mentioned principle, its place in the system of principles of labour law.

In the doctrine of labour law, social dialogue is recognized as one of the main principles of legal regulation of labour relations. This conclusion is reached by both the researchers who determine the definition of the 
social dialogue in the field of labour ${ }^{1}$, and the researchers, who study the system of principles of labour law ${ }^{2}$.

As one of the basic principles of modern labour law, the principle of social dialogue in the field of labour may be defined as a guiding idea, a fundamental foundation that expresses the essence, basic characteristics and general orientation of the norms of the legal institutes of collective labour law, as well as particular institutes of individual labour law.

Particular attention should be paid to the importance of the systematic approach to the study of the principles of legal regulation of labour relations that exists in the modern doctrine of labour law. Thus, I.P. Zhigalkin emphasizes that the consistency of the system of the principles of labour law requires:

a) their conformity with each other,

b) a unified approach to their understanding and application,

c) taking into account the nature and content of heterogeneous principles,

d) on the one hand, a differentiated, and on the other hand - an integrated approach to the legal regulation of relations in the field of labour,

e) compliance of the principles of labour law with the true interests of society and the state. Each of the principles can be interpreted and applied only with respect to the essence of the other principles connected with $\mathrm{it}^{3}$.

There is no single approach to the determination of the place of the principle of the social dialogue in the system of principles of labour law. This is explained by the existence of different classifications of the principles of legal regulation of labour relations.

Thus, carrying out the classification of the principles of labour law, I.P. Zhigalkin distinguishes fundamental, general and special principles ${ }^{4}$. Fundamental are those that form the basis of labour law as a whole, which

${ }^{1}$ Чанишева Г.І. Колективні відносини у сфері праці: теоретико-правовий аспект: Монографія. Одеса: Юридична література, 2001. С. 98; Сорочишин М.В. Правові аспекти соціального діалогу у сфері праці: Монографія. Одеса: Юридична література, 2014. С. 91.

${ }^{2}$ Паньков Д.А. Принципи правового регулювання трудових відносин: автореф. дис. ...канд. юрид. наук: 12.00.05. Одеса, 2007. С. 11; Жигалкін І.П. Система принципів трудового права в умовах формування нової правової доктрини України: автореф. дис. ...докт. юрид. наук: 12.00.05. К., 2016. С. 7.

${ }^{3}$ Жигалкін І. П. Система принципів трудового права в умовах формування нової правової доктрини України [Текст]: дис. ... д-ра юрид. наук: 12.00.05 /Східноукраїнський національний університет імені Володимира Даля. Сєвєродонецьк, 2016. С. 166.

${ }^{4}$ Жигалкін І. П. Система принципів трудового права в умовах формування нової правової доктрини України [Текст]: дис. ... д-ра юрид. наук: 12.00.05 /Східноукраїнський національний університет імені Володимира Даля. Сєвєродонецьк, 2016. С. 165-166. 
acts as a mandatory social regulator of labour and related relations and serve as the embodiment of the most important values, inherent to this field of law. These include humanism, social justice and equality. General and special principles, as derivatives from the fundamental principles, ensure their implementation. General principles reflect the specifics of labour law as an independent branch of law, its place and purpose in the national system of law, and determine the focus of its norms. Special principles are the guiding ideas that develop the essence of the norms of one or more institutes (sub-institutes) of labour law.

I.P. Zhigalkin singles out as one of the fundamental principles of labour law the principle of equality and considers it as a basic one for a number of principles of legal regulation of relations in the field of labour, including the principle of social dialogue in the field of labour.

In the doctrine of labour law exists another classification of the principles of legal regulation of labour relations, according to which these principles are divided into four main groups:

1) those that express the policy of the state in the field of legal regulation of the labour market and effective employment;

2) those containing the guidelines in the field of the establishment of working conditions;

3) those that determine the legal regulation of the employment of waged workers;

4) those that reflect the main directions of legal policy in the field of health care and protection of labour rights of workers ${ }^{5}$.

According to this classification, the principle of social partnership is included into the group of principles that determine the establishment of working conditions of employees. At the same time, the emphasis is on the right to participation of workers, employers, their associations in the contractual regulation of labour relations and other directly related relations.

N.B. Bolotina believes that the principle of social partnership is inherent to collective labour law. This principle is complex in its character and composition and includes the following principles-rights: the right of workers and employers for association in order to protect their rights and interests; freedom of association; equality of rights and opportunities.

In our opinion, the above-mentioned approaches to the definition of the place of the principle of social dialogue in the system of principles of labour law carry a narrow understanding of the content of this principle.

${ }^{5}$ Трудовое право: учеб. /Н.А. Бриллиантова и др.; под ред. О.В. Смирнова, И.О. Снигиревой. 3-е изд., перераб. и доп. М.: ТК Велби, Изд-во Проспект, 2007. С. 26. 
One cannot agree with N.B. Bolotina that the principle of social partnership is typical only for collective labour law. This principle is also applied to the regulation of individual labour relations, which has recently become more and more manifest in the norms of such institutes of individual labour law as working time, leisure time, remuneration, health protection of workers at the production site.

If we follow the existing approach in the doctrine of labour law to the definition of the system of principles of labour law as a set of principles of legal regulation of individual labour relations (the principles of individual labour law), the principles of legal regulation of collective labour relations (principles of collective labour law) and the principles inherent to the labour law in general, then in this system the principle of social dialogue in the field of labour belongs to the last group of principles, that is, those which are guiding ideas, fundamental foundations of legal regulation of individual and collective labour relations, which are distinguished in the subject matter of labour law.

At the same time, there is no unity among scholars regarding the definition of the content of the principle of social dialogue in the field of labour. The complex nature of this principle is noted in the literature. According to N.B. Bolotina, the principle of social partnership is complex in nature and composition. The researcher includes in it the following principles-rights: the right of workers and employers to association in order to protect their rights and interests; freedom of association; equality of rights and opportunities ${ }^{6}$.

D.A. Pankov also notes the complex nature of the principle of the social dialogue in the field of labour and includes into its contents the principles of real recognition of the right to collective bargaining and ensuring the participation of employees and their representatives in the management of the organization ${ }^{7}$.

In our opinion, such position of researchers cannot be agreed with. The principles of freedom of association, equality of rights and opportunities, effective recognition of the right to collective bargaining and ensuring the participation of employees and their representatives in the management of the organization in international legal acts are recognized as independent principles in the field of labour and are not considered as elements of the principle of social dialogue. Thus, the ILO Declaration of

\footnotetext{
${ }^{6}$ Болотіна Н.Б. Трудове право України: Підручник. 5-те вид., перероб. і доп. К.: Знання, 2008. C. 197.

7 Паньков Д.А. Принципи правового регулювання трудових відносин: автореф. дис. ...канд. юрид. наук: 12.00.05. Одеса, 2007. С. 11.
} 
18 June 1998 proclaimed four fundamental principles and rights in the field of labour, including freedom of association and the effective recognition of the right to collective bargaining. To the realization of the principle of ensuring the participation of employees and their representatives in the management of an organization are devoted the ILO Recommendation No. 94 on Co-operation at the Level of the Undertaking of 1952 and the ILO Recommendation No. 129 on Communications within the Undertaking of 1967.

Some scholars narrow down the content of the principle of the social dialogue to some extent, linking it only with the collective-contractual regulation of labour relations and the resolution of collective labour disputes ${ }^{8}$.

At the same time, in the ILO practice to the social dialogue are included all types of negotiations, consultations and simply the exchange of information between or among representatives of the government, employers and employees concerning common interests related to economy and social policy. The ILO considers social dialogue to be the most successful means of improvement of living conditions and working conditions and establishment of social justice ${ }^{9}$.

The content of the principle of social dialogue in the field of labour is associated with the participation of workers, employers and their representatives (trade unions, their associations, employers' organizations, their associations) in the contractual regulation of individual and collective labour relations. In a civilized society, it is on the basis of the social dialogue, contractual establishment of working conditions that a balance is struck between the productive and social interests of employers and workers, since centralized regulation alone does not allow this objective to be achieved.

However, the content of the principle of social dialogue should not be reduced only to the participation of workers, employers and their representatives in the establishment of mutually acceptable working conditions. This principle requires the need for constructive cooperation between the parties to the social dialogue at different levels (national, sectoral, territorial, local) to reconcile their objectively opposing interests, finding a compromise, achieving socially meaningful and useful results. This follows from article 1 of the Law of Ukraine "On the Social Dialogue

\footnotetext{
${ }^{8}$ Сорочишин М.В. Правові аспекти соціального діалогу у сфері праці: Монографія. Одеса: Юридична література, 2014. С. 91.

${ }^{9}$ Social Dialogue: all partners for decent work. International Labour Office. Geneva, 2007.
} 
in Ukraine" of December 23, 2010, No. 2862-VI ${ }^{10}$, which formulates the definition of the social dialogue as a process of identifying and converging positions, achieving common agreements and making agreed decisions by parties to the social dialogue, representing interests of employees, employers and executive authorities and bodies of local self-government, on the issues of formation and realization of state social and economic policy, regulation of labour, social and economic relations.

This principle became the basis of legal regulation of creation and operation of social dialogue bodies in the field of labour (National Tripartite Social and Economic Council, sectoral (intersectoral) tripartite or bilateral socioeconomic councils, territorial tripartite socioeconomic councils), different forms of interaction and cooperation of the parties to the social dialogue: information exchange; consultations; conciliation procedures; collective bargaining on the conclusion of collective agreements; realization by representatives of employees of the rights in the field of informing and consulting, as well as other rights related to participation in the making of decisions by the employer; participation of employees and their representatives in the management of the organization; conciliation procedures for resolving labour disputes; implementation of joint control over fulfilment of obligations under collective agreements; participation of employees in the distribution of profit of organizations, etc.

Under the new economic conditions, the content of the principle of social dialogue in the field of labour is increasingly expanding. Specification of this principle is carried out in the norms of various institutes of labour law. These are such institutions of collective labour law as the legal bases for social dialogue in the field of labour, the legal status of labour collectives, the legal status of trade unions, their associations, the legal status of employers' organizations, their associations, collective agreements, the resolution of collective labour disputes (conflicts). Increasingly the principle of social dialogue is reflected in the norms of the institutes of individual labour law, such as, for example, working time, leisure time, remuneration, occupational safety and health of workers in the workplace. It is in the norms of these institutions that the contracting method of regulating labour relations, connected with the conclusion of collective agreements, other agreements, is further developed.

\footnotetext{
${ }^{10}$ Про соціальний діалог в Україні: Закон України від 23.12.2010 № 2862-VI. Відомості Верховної Ради України. 2011. № 28. Ст. 255.
} 
The principle of social dialogue in the field of labour, as well as other principles of legal regulation of labour relations, is not enshrined in the Code of Laws on Labour of Ukraine, which is its essential disadvantage.

This principle is also not mentioned in article 2 "Basic principles of legal regulation of labour relations" of the draft Labour Code of Ukraine. In article 2 prepared for the second reading of the bill of July 24, 2017, there are 15 principles left, most of which are the principles of legal regulation of individual labour relations. The principles of legal regulation of collective labour relations include only the principle of ensuring the right of workers and employers to freedom of association for the representation and protection of their rights and interests. This approach of the drafters of the Labour Code of Ukraine to the system of basic principles of labour law is questionable.

It is also advisable to consider social dialogue in the field of labour as a system of collective labour relations that occur at national, sectoral, territorial and local levels. These are the following types of collective labour relations with: participation of employees in the management of an enterprise, institution, organization; participation of labour collectives in setting and changing working conditions; collective bargaining on the conclusion of collective agreements and collective contracts; implementation of collective agreements and collective contracts and control over their implementation; the activities of trade unions, their associations representing and protecting the rights and interests of employees; the activities of employers' organizations, their associations representing and protecting the rights and interests of employers; the resolution of collective labour disputes (conflicts).

The definition of social dialogue in the field of labour as a system of collective labour relations is consistent with the title of the Sixth book "Collective Labour Relations" of the Draft Labour Code of Ukraine.

Collective labour relations may be defined as volitional social relations, regulated by the norms of labour law, within which their subjects exercise collective labour rights and perform their corresponding duties in accordance with the current labour law.

Collective labour relations are characterized by general features of legal relations, formulated in the theory of law. Specific features of collective labour relations include the following: they arise and function at all levels of the social dialogue - national, sectoral, territorial and local; constitute a tripartite or bilateral legal relations; their subjects are, as a rule, collective entities (except for the local level, at which according to article 4 of the Law of Ukraine "On the Social Dialogue in Ukraine" it is 
provided for the participation of the employer and the employee's representative); their legal content is made up of collective labour rights and corresponding responsibilities; in these relationships collective (corporate) interests are realized; there is representation of the interests of workers, employers, the state, making it different from the institution of representation in civil law.

The legal content of collective labour relations is made up of the rights and duties of their subjects. The specificity of the content of the specified legal relationships is that collective labour rights of employees, employers (their representatives) are realized within their framework. The international legal acts enshrine such collective labour rights as the right of workers and employers to freedom of association, the right of employees to participate in the management of the organization, the right of workers and employers to collective bargaining and the conclusion of collective agreements, the right of workers and employers (their representatives) on information and consultations, the right of workers and employers to resolve collective labour disputes (conflicts) (European Social Charter (revised) provides for the right of workers and employers collective action, including the right to strike), the right of employees to receive information and advice during collective dismissal.

Conclusion on the relationship of collective labour relations with legal relations from social dialogue in the field of labour is one of the leading in the theory of collective labour relations. Social dialogue in the field of labour should be considered as a system of collective labour relations between workers, employers and their representatives, executive bodies, other subjects of these relations, which arise in the process of realization of their collective labour rights and interests. Legal relations within the social dialogue in the field of labour actually exist as a specific kind of collective labour relations.

\section{Social dialogue as an institute of labour law}

In the legal literature, two approaches to defining the legal concept of social partnership are the most common. The first approach is to define social partnership as a legal institute, although the views of scholars on the content and structure of this institute differ ${ }^{11}$. The second approach is related to a broader understanding of social partnership, in connection with

${ }^{11}$ Трудовое право России /под ред. А.М. Куренного. М.: Юристъ, 2006. С. 125; Пашков А.С. Избранные труды по трудовому праву. СПб : Изд. Дом СПб гос. ун-та, изд-во юрид. фак., 2006. С. 436; Трудовое право: учебник для бакалавров / отв. ред. К.Н. Гусов. М.: Проспект, 2015. С. 155. 
which the concept is considered in several meanings (aspects), and the views of the proponents of this approach do not coincide.

Thus, in the Great Encyclopedic Legal Dictionary, social partnership is defined in two respects as: 1) a system of developed relationships between employees, employers, as well as the state on the basis of cooperation, compromises, agreed decisions on social and labour relations; 2) the principle of social policy of the state, which ensures the fair distribution of material resources between the parties of social relations in a market economy ${ }^{12}$.

According to S.M. Prilipko, O.M. Yaroshenko, N.M. Klymenchuk, social partnership can be characterized as: a) a legal institute, which is a set of legal norms, governing a group of interrelated relations between employees, employers and the state; b) a legal principle that reflects the guiding idea, characterizing the patterns of reconciliation of interests of the subjects of social partnership; c) social relations between employees, employers and the state, in which each of their participants acts as the bearer of subjective rights and responsibilities; d) a legal mechanism in the regulation of social and labour relations ${ }^{13}$.

According to A.M. Lushnikov and M.V. Lushnikova, social partnership should be viewed as a legal mechanism for regulation of collective relations, which includes the regulatory and protective parts ${ }^{14}$. Researchers point out that collective (social partnership) relations arise with regard to collective bargaining and the conclusion of collective agreements and contracts; participation of employees and their representatives in the management of an organization, trade union representation and protection of workers' rights, mutual consultations, negotiations on the regulation of labour relations. This is covered by the regulatory part of the legal mechanism of social partnership. The protective part of the legal mechanism of social partnership includes the conciliation procedure for the settlement of collective labour disputes, including the right to strike.

V.A. Safonov defines social partnership as a way of regulating social and labour relations between employees (their representatives) and employers (their representatives), based on mutual consideration of

12 Великий енциклопедичний юридичний словник /За редакцією акад. НАН України Ю.С. Шемшученка. К.: ТОВ «Видавництво «Юридична думка», 2007. С. 825-826.

${ }^{13}$ Прилипко С.М., Ярошенко О.М., Клименчук Н.М. Колективні угоди як результат соціального партнерства (сучасний стан і перспективи розвитку ). Х.: Вид-во «ФІНН», 2011. C. 11.

14 Лушников А.М., Лушникова М.В. Курс трудового права: Учебник: В 2 т. Т. 2. Коллективное трудовое право. Индивидуальное трудовое право. Процессуальное трудовое право. М.: Статут, 2009. С. 40. 
interests of each party, respect for those interests and refusal of forceful ways of interaction ${ }^{15}$.

Other definitions of the legal concept of the social partnership in the field of labour are formulated by modern researchers: the legal mechanism of regulation of collective relations ${ }^{16}$; element of the mechanism of protection of labour rights of workers ${ }^{17}$; method and mechanism of regulation of social-labor relations and dispute settlement between employees and employers ${ }^{18}$ etc.

In the legislation of most post-Soviet states, the concept of social partnership is defined as a system of relations between employees (employees' representatives), employers (employers' representatives), and bodies of state power. Thus, in accordance with article 1 of the Labour Code of the Republic of Kazakhstan of November 23, 2015 social partnership is a system of relations between employees (employees' representatives), employers (representatives of employers), bodies of state power, aimed at ensuring the harmonization of their interests in matters of regulation of labour relations and other relations directly related to employment. A similar definition of the concept of social partnership is provided in article 23 of the Labour Code of Russian Federation of December 30, 2001.

Close in the content to the above mentioned formulation was the definition of social partnership in part 1 of article 40 of the Labour Code of the Republic of Lithuania of 4 June 2002 as a system of relations between representatives of employees and employers and their organizations, and in some cases established by this Code and other laws also state institutions, with the means of which it is necessary to reconcile the interests of the subjects of labour relations. However, the definition of social partnership is not provided in the new Labour Code of the Republic of Lithuania of 14 September 2016. In article 161, Section I "General Provisions" of Part III of "Collective Labour Relations" only the aim and principles of social partnership in labour relations were set out.

The concept of social partnership in article 352 of the Labour Code of the Republic of Belarus of July 26, 1999 is different from the definitions,

\footnotetext{
${ }^{15}$ Социальное партнерство: учебник для бакалавриата и магистратуры /В.А. Сафонов. М.: Издательство Юрайт, 2015. С. 36.

${ }^{16}$ Жернаков В.В. Договірне регулювання соціально-трудових відносин. Вісник Академії правових наук України. 2010. № 4. С. 237.

17 Сошникова Т.А. Социальное партнерство как важнейший механизм защиты трудовых прав работников. Труды Ин-та гос-ва и права Рос. акад. наук. 2008. № 1. С. 108.

${ }^{18}$ Гордон Л.А. На пути к социальному партнерству. Развитие социально-трудовых отношений в современной России. М.: ИНФРА, 1998. С. 48-57.
} 
provided above. According to the latter definition social partnership is a form of interaction between bodies of public administration, employers' associations, trade unions and other representative bodies of employees, authorized in accordance with the acts of the law to represent their interests (subjects of social partnerships) during the development and implementation of the socio-economic policy of the state, based on taking into account the interests of different sections and groups of society in the social and labour sphere through negotiations, consultations, nonconfrontation and s absense of social conflicts.

The presence of a large number of definitions of the legal concept of social partnership indicates its complexity and versatility.

In specifying the definition of this legal category, it should be taken into consideration that the term "social partnership" has been replaced in the national legislation by the term "social dialogue", as well as the fact that the term "social dialogue" is used in international legal practice, in particular in the acts and publications of the ILO, more often than the "social partnership".

The term "social dialogue" was introduced into national legislation by the Decree of the President of Ukraine "On the Development of Social Dialogue in Ukraine" of December 29, 2005. Legal foundations of the organization and procedure for conducting social dialogue were later established in the Law of Ukraine "On the Social Dialogue in Ukraine" of December 23, 2010. In the Law of Ukraine "On Employers' Organizations, their Associations, Rights and Guarantees of Their Activities" of June 22, 2012 No. 5026-VI the term "social dialogue" is used instead of the term "social partnership".

National legislation is characterized not only by the use of the term "social dialogue" instead of the term "social partnership", but also by defining the content of the term.

Some authors hold the view that social dialogue and social partnership are two separate concepts. As V.O. Protsevsky specifies, social dialogue is only a process of defining and converging the positions of its participants, it is consultation and negotiation; the achievement of joint agreements and the adoption of agreed decisions by the subjects of legal relations in the field of wage labour constitute social partnership ${ }^{19}$. Analyzing the principles of social dialogue and its parties the researcher believes that there is a transformation of social dialogue into social partnership.

${ }^{19}$ Процевський В.О. Приватно-правове та публічно-правове регулювання соціальнотрудових відносин: монографія. Х.: ХНАДУ, 2012. С. 280. 
It seems that in this case there is a dispute solely about the terms, not the essence of this legal phenomenon. In general, the discussion of the differences between the terms "social dialogue" and "social partnership" seems unjustified and unpromising. Since the term "social dialogue" ha been used in national legislation for more than 10 years, the representatives of the doctrine should also adhere to the single terminology, even if the term "social partnership" is more appropriate in the view of some scholars.

In our opinion, in addition to the legislative fixation of the definition of social dialogue in article 1 of the Law of Ukraine "On the Social Dialogue in Ukraine" as a process of defining and converging positions, reaching common agreements and making agreed decisions by the parties to the social dialogue, social dialogue can be considered as: 1) one of the basic principles of legal regulation of labour relations; 2) the system of collective labour relations; 3) as an institute of labour law.

As a principle of legal regulation of labour relations, the principle of social dialogue in the field of labour belongs to the fundamental guiding principles that determine the content of modern labour law and directions for its further development. As one of the basic principles of legal regulation of labour relations, the principle of social dialogue in the field of labour should be envisaged in article 2 of the draft Labour Code of Ukraine.

It is also advisable to consider social dialogue in the field of labour as a system of collective labour relations that occur at national, sectoral, territorial and local levels. These are the following types of collective labour relations with: participation of employees in the management of an enterprise, institution, organization; participation of labour collectives in setting and changing working conditions; collective bargaining on the conclusion of collective agreements and collective agreements; implementation of collective agreements and collective agreements and control over their implementation; the activities of trade unions, their associations representing and protecting the rights and interests of employees; the activities of employers' organizations, their associations representing and protecting the rights and interests of employers; the resolution of collective labour disputes (conflicts).

The definition of social dialogue in the field of labour as a system of collective labour relations is consistent with the title of the Sixth book "Collective Labour Relations" of the draft Labour Code of Ukraine.

The legislation of Ukraine on social dialogue in the field of labour is based on the Constitution of Ukraine and consists of international treaties 
ratified by Ukraine, the Code of Laws on Labour of Ukraine, laws of Ukraine "On the Social Dialogue in Ukraine", "On Collective Agreements", "On Remuneration" , "On the procedure for resolving collective labour disputes (conflicts)", "On trade unions, their rights and guarantees of activity", "On the organization of employers, their associations, rights and guarantees of their activities", by-laws, acts of social dialogue (collective agreements, collective contracts, other acts).

The norms contained in these normative acts, in their entirety, correspond to the characteristics of the institute of law. In the theory of law, an institute of law is defined as an objectively distinct within a single branch or several branches of law set of interrelated legal norms, governing a small group of specific family of relationships ${ }^{20}$. A legal institute is characterized by a general content of legal norms, a semantic connection between them, a logical unity that causes them to be separated within a branch of law or, as an exception, between several branches of law.

As an independent institute of labour law, social dialogue in the field of labour is a set of legal norms that enshrine concepts, basic principles of social dialogue, levels and parties, criteria of representativeness for the subjects of trade union side and employers' side, forms of social dialogue, legal status of bodies of social dialogue, control and responsibility of the parties to social dialogue.

Defining social partnership as a legal institute, researchers have not reached a consensus on the place of this institute in the system of labour law. In the doctrine social partnership is considered as a new institute of the general part of labour law ${ }^{21}$ or as a new general institute of "social partnership", which has a complex structure and includes a sub-institute of collective contracts, collective agreements (O.V. Smirnov and others) ${ }^{22}$.

S.M. Prylypko, O.M. Yaroshenko, N.M. Klymenchuk define the content of the legal institute of social partnership as a set of legal norms governing a group of interrelated relations between employees, employers and the state. However, at the same time, researchers do not specify what the relations in question are, and do not determine the place of this institute in the system of labour law.

Social dialogue in the field of labour should be recognized an independent institute of labour law. It is an integral part of the collective

\footnotetext{
${ }^{20}$ Общетеоретическая юриспруденция: учебный курс: учебник / под ред. Ю.Н. Оборотова. О.: Феникс, 2011. С. 115.

${ }^{21}$ Трудовое право России: Учебник для вузов / Под ред. С.Ю. Головиной, М.В. Молодцова. М.: Изд-во Норма, 2010. С. 116.

22 Комментарий к Трудовому кодексу РФ: постатейный / Под ред. О.В. Смирнова. 2-е изд., перераб. и доп. М.: Проспект (ТК Велби), 2005. С. 80-81.
} 
labour law as a structural element in the system of labour law of Ukraine. Collective labour law, in addition to the specified institute, includes the following institutes: legal status of labour collectives; legal status of trade unions, their associations; the legal status of employers' organizations, their associations; collective agreements and collective contracts; the resolution of collective labour disputes (conflicts).

\section{CONCLUSIONS}

As one of the basic principles of modern labour law, the principle of social dialogue in the field of labour is a guiding idea, a fundamental foundation that expresses the essence, basic characteristics and general orientation of the norms of the legal institutes of collective labour law, as well as specific institutes of individual labour law.

In the system of principles of labour law, the principle of social dialogue in the field of labour belongs to the principles inherent to labour law in general, that is, those that are guiding ideas, the basic principles of legal regulation of individual and collective labour relations, which are distinguished in the subject matter of labour law.

The principle of the social dialogue in the field of labour is the fundamental foundation of the legal regulation of the participation of employees, employers and their representatives in the contractual regulation of individual and collective labour relations, the creation and operation of the bodies of the social dialogue, various forms of interaction and cooperation of the parties to the social dialogue at different levels: information exchange; consultations; conciliation procedures; collective bargaining on the conclusion of collective agreements; realization by the representatives of employees of the rights in the field of informing and consulting, as well as other rights related to participation in the adoption of decisions by the employer; participation of employees and their representatives in the management of the organization; conciliation procedures for resolving labour disputes; implementation of joint control over fulfilment of obligations under collective agreements; participation of employees in the distribution of profit of organizations, etc.

The list of principles enshrined in article 2 of the draft Labour Code of Ukraine does not include some principles that should indeed be recognized as the starting point, the main provisions of the legal regulation of labour relations. These include the principle of social dialogue in the field of labour, which needs to supplement the list of basic principles of legal regulation of labour relations in article 2 of the draft Labour Code of Ukraine. 
It is also advisable to consider social dialogue in the field of labour as a system of collective labour relations that arise at the national, sectoral, territorial and local levels. These are the following types of collective labour relations regarding: the participation of employees in the management of an enterprise, institution, organization; participation of labour collectives in setting and changing working conditions; collective bargaining on the conclusion of collective agreements and collective contracts; implementation of collective agreements and collective contracts and control over their implementation; the activities of trade unions, their associations representing and protecting the rights and interests of employees; the activities of employers' organizations, their associations representing and protecting the rights and interests of employers; the resolution of collective labour disputes (conflicts).

Social dialogue in the field of labour is an independent institute of labour law. It is an integral part of collective labour law as a structural element in the system of labour law of Ukraine. Collective labour law, in addition to the specified institute, includes the following institutes: legal status of labour collectives; the legal status of trade unions, their associations; the legal status of employers' organizations, their associations; collective agreements and collective contracts; the resolution of collective labour disputes (conflicts).

The contents of the institute is formed by the legal norms that enshrine the definition, basic principles of social dialogue, levels and parties, criteria of representativeness for the subjects of trade union side and employer side, forms of social dialogue implementation, legal status of social dialogue bodies, control and responsibility of the parties to the social dialogue.

The current Labour Code of Ukraine does not contain any special rules on the social dialogue in the field of labour. Unfortunately, a separate chapter 1 "Social Dialogue", was excluded from Book 6 "Collective Labour Relations" of the draft Labour Code of Ukraine № 1658. Despite the importance of social dialogue, its legal foundations are not enshrined in the draft law, which is something we cannot agree with. The position of the developers of the Draft law is not consistent with the structure and content of the new labour codes adopted in post-socialist countries, which include separate sections (chapters) on social partnership.

It seems appropriate to change the name of the Book 6 of the draft Labour Code of Ukraine and to call it "Social Dialogue in the Field of Labour. Collective Labour Relations». In two separate articles of this Book it is necessary to consolidate the definition, principles and tasks of the social dialogue, as well as the system and organization of the social dialogue in the field of labour. 


\section{SUMMARY}

The concept of social dialogue in the field of labour should be considered as one of the basic principles of labour law, as a system of collective labour relations and as a legal institute in the system of this field.

The concept and the content of the principle of the social dialogue in the field of labour are defined. The place of the principle of the social dialogue in the field of labour in the system of principles of labour law is ascertained. Proposals on the implementation of the principle of the social dialogue in the field of labour in the current Code of Laws on Labour of Ukraine, draft Labour Code of Ukraine are introduced.

Social dialogue in the field of labour is a system of collective labour relations that arise at the national, sectoral, territorial and local levels. These are the following types of collective labour relations regarding: the participation of employees in the management of an enterprise, institution, organization; the participation of labour collectives in setting and changing of working conditions; collective bargaining on the conclusion of collective agreements and collective contracts; implementation of collective agreements and collective contracts and control over their implementation; the activities of trade unions, their associations regarding representation and protection of the rights and interests of employees; the activities of employers' organizations, their associations representing and protecting the rights and interests of employers; the resolution of collective labour disputes (conflicts).

The social dialogue in the field of labour as an institution of labour law is determined. The contents of the indicated institute and its place in the system of modern labour law in Ukraine are identified. As an independent institute of labour law, social dialogue in the field of labour is a set of legal norms that enshrine definition, basic principles of social dialogue, levels and parties, criteria of representativeness for the subjects of trade union side and employers' side, forms of social dialogue, legal status of bodies of social dialogue, control and responsibility of the parties to social dialogue. Proposals on fixation of the norms of the institute of social dialogue in the field of labour in the draft Labour Code of Ukraine are introduced. 


\section{REFERENCES}

1. Чанишева Г.І. Колективні відносини у сфері праці: теоретикоправовий аспект: Монографія. Одеса: Юридична література, $2001.328 \mathrm{c}$.

2. Сорочишин М.В. Правові аспекти соціального діалогу у сфері праці: Монографія. Одеса: Юридична література, 2014. 208 с.

3. Паньков Д.А. Принципи правового регулювання трудових відносин: автореф. дис. ... канд. юрид. наук: 12.00.05. Одеса, 2007. 20 с.

4. Жигалкін І.П. Система принципів трудового права в умовах формування нової правової доктрини України: автореф. дис. ... докт. юрид. наук: 12.00.05. К., 2016. 40 с.

5. Жигалкін І. П. Система принципів трудового права в умовах формування нової правової доктрини України [Текст]: дис. ... д-ра юрид. наук: 12.00.05 / Східноукраїнський національний університет імені Володимира Даля. Сєвєродонецьк, 2016. 442 с.

6. Трудовое право: учеб. /Н.А. Бриллиантова и др.; под ред. О.В. Смирнова, И.О. Снигиревой. 3-е изд., перераб. и доп. М.: ТК Велби, Изд-во Проспект, 2007. 600 с.

7. Болотіна Н.Б. Трудове право України: Підручник. 5-те вид., перероб. і доп. К.: Знання, 2008. 860 с.

8. Social Dialogue: all partners for decent work. International Labour Office. Geneva, 2007.

9. Про соціальний діалог в Україні: Закон України від 23.12.2010 № 2862-VI. Відомості Верховної Ради України. 2011. № 28. Ст. 255.

10. Трудовое право России /под ред. А.М. Куренного. М.: Юристъ, 2006. $496 \mathrm{c}$.

11.Пашков А.С. Избранные труды по трудовому праву. СПб : Изд. Дом СПб гос. ун-та, изд-во юрид. фак., 2006. 520 с.

12. Трудовое право: учебник для бакалавров / отв. ред. К.Н. Гусов. М.: Проспект, 2015. 632 с.

13. Великий енциклопедичний юридичний словник / За редакцією акад. НАН України Ю.С. Шемшученка. К.: ТОВ «Видавництво «Юридична думка», 2007. 992 с.

14.Прилипко С.М., Ярошенко О.М., Клименчук Н.М. Колективні угоди як результат соціального партнерства (сучасний стан і перспективи розвитку ). Х.: Вид-во «ФІНН», 2011. 256 с.

15.Лушников А.М., Лушникова М.В. Курс трудового права: Учебник: В 2 т. Т. 2. Коллективное трудовое право. Индивидуальное трудовое право. Процессуальное трудовое право. М.: Статут, 2009. $1151 \mathrm{c}$. 
16.Социальное партнерство: учебник для бакалавриата и магистратуры / В.А. Сафонов. М.: Издательство Юрайт, 2015. 395 с.

17.Жернаков В.В. Договірне регулювання соціально-трудових відносин. Вісник Академії правових наук України. 2010. № 4. С. 237.

18. Сошникова Т.А. Социальное партнерство как важнейший механизм защиты трудовых прав работников. Труды Ин-та гос-ва $u$ права Рос. акад. наук. 2008. № 1. С. 108.

19.Гордон Л.А. На пути к социальному партнерству. Развитие социально-трудовых отношений в современной России. М.: ИНФРА, $1998.256 \mathrm{c}$.

20.Процевський В.О. Приватно-правове та публічно-правове регулювання соціально-трудових відносин: монографія. Х.: ХНАДУ, 2012. $330 \mathrm{c}$.

21.Общетеоретическая юриспруденция: учебный курс: учебник / под ред. Ю.Н. Оборотова. О.: Феникс, 2011. 436 с.

22. Трудовое право России: Учебник для вузов / Под ред. С.Ю. Головиной, М.В. Молодцова. М.: Изд-во Норма, 2010. 704 с.

23. Комментарий к Трудовому кодексу РФ: постатейный / Под ред. О.В. Смирнова. 2-е изд., перераб. и доп. М.: Проспект (ТК Велби), 2005. 784 c.

Information about the author:

Chanysheva G. I.,

Doctor of Legal Sciences, Professor, Corresponding Member of the National Academy of Legal Sciences of Ukraine, Dean of the Socio-Legal Faculty, National University “Odessa Law Academy” 2, Academychna str., Odessa, 65009, Ukraine 